$11-2013$

\title{
Controls of Phosphorus Loading and Transport in the Cuyahoga River of Northeastern Ohio, USA
}

\author{
Fasong Yuan \\ Cleveland State University, f.yuan06@csuohio.edu \\ Jaime A. Quellos \\ Cleveland State University \\ Chaojun Fan \\ Cleveland State University
}

Follow this and additional works at: https://engagedscholarship.csuohio.edu/scibges_facpub

Part of the Biology Commons

How does access to this work benefit you? Let us know!

\section{Publisher's Statement}

NOTICE: this is the author's version of a work that was accepted for publication in Applied Geochemistry. Changes resulting from the publishing process, such as peer review, editing, corrections, structural formatting, and other quality control mechanisms may not be reflected in this document. Changes may have been made to this work since it was submitted for publication. A definitive version was subsequently published in Applied Geochemistry, 38, November, 2013 DOI:10.1016/j.apgeochem.2013.08.011

\section{Recommended Citation}

Yuan F, Quellos JA, Fan C. 2013. Controls of phosphorus loading and transport in the Cuyahoga river of northeastern Ohio, USA. Appl Geochem. 38:59-69.

This Article is brought to you for free and open access by the Biological, Geological, and Environmental Sciences Department at EngagedScholarship@CSU. It has been accepted for inclusion in Biological, Geological, and Environmental Faculty Publications by an authorized administrator of EngagedScholarship@CSU. For more information, please contact library.es@csuohio.edu. 


\title{
Controls of phosphorus loading and transport in the Cuyahoga River of northeastern Ohio, USA
}

\author{
Fasong Yuan*, Jaime A. Quellos, Chaojun Fan \\ Department of Biological, Geological, and Environmental Sciences, Cleveland State University, 2121 Euclid Ave, Cleveland, OH 44115, USA
}

\section{Introduction}

Phosphorus (P) is essential to the growth of plants and algae in freshwater ecosystems (Schindler, 1974; Schindler et al., 2008). Excessive P loading from point sources (e.g., effluents from wastewater treatment plants) and diffuse sources such as urban and agricultural runoff often results in cultural eutrophication (Carpenter et al., 1998; Correll, 1998). As a recurring symptom of eutrophication in Lake Erie, blooms of harmful algae (Cladophora spp. and Microcystis spp.) contribute to many water quality degradation problems, including foul odors, poor water clarity, summer hypoxia, and fish kills (Beeton, 1961; Hawley et al., 2006). After years of rigorous management efforts to reduce the total phosphorus (TP) loading from point sources and diffuse sources to the lake, its target tributary loading of $11,000 \mathrm{Mg}$ TP per year was first reached in 1983 and has been maintained more or less since then (Dolan and Chapra, 2012; Dolan and McGunagle, 2005; Schwab et al., 2009). Despite early success from these management efforts, blooms of harmful algae have increased aggressively in western Lake Erie since the mid-1990s (Conroy et al., 2005; Michalak et al., 2013; Stumpf et al., 2012), highlighting a shortcoming of the existing models that were used to establish the guidelines for contemporary P management practices in the basin (Schwab et al., 2009).

Over the last decades, much of the research attention has been focused on the loading of TP from large agricultural watersheds such as the Maumee and Sandusky Rivers in the Lake Erie basin (e.g., Baker and Kramer, 1973; Richards et al., 2009). Since the mid-1980s, the TP loading of these watersheds has been decreasing due to the use of conservation tillage practices (Myers et al., 2000; Richards et al., 2009). While viewed as an effective measure to reduce erosion, such practices have caused $P$ stratification in soil columns (Crumrine, 2009), leading to a substantial increase in the loading of soluble reactive phosphorus (SRP) in agricultural runoff (Daloğlu et al., 2012; Michalak et al., 2013; OEPA, 2010). Coupled with favorable hydroclimatic and limnological conditions (e.g., weak lake circulation and prolonged algae incubation) (Michalak et al., 2013), the increased loading of SRP from these watersheds was thought to have triggered the recent resurge of massive algal blooms in western Lake Erie (Daloğlu et al., 2012; OEPA, 2010).

On the other hand, P-bearing effluents from wastewater treatment plants (WWTPs) have repeatedly been reported to have a greater risk to water quality and biological integrity of streams 
and lakes (Carey and Migliaccio, 2009; Jarvie et al., 2006; OEPA, 1999). The Greater Cleveland-Akron metropolis as one of the largest population centers along the southern costal of Lake Erie, with a population of about 2 millions, generates about $300 \mathrm{Mg} / \mathrm{yr}$ of effluent TP from over a dozen WWTPs which accounts for over $15 \%$ of the total municipal loading to the lake. Because a large fraction of the municipal wastewater (including combined sewer overflows) is released directly into the Cuyahoga River and its tributaries (OEPA, 2003), the municipal P loading may have already posed a disproportionately greater threat to ecological health of Lake Erie. Since the early work by Schroeder and Collier (1966), the Cuyahoga River has been the subject of many water quality studies, e.g., stream water chemistry (Lo and Shong, 1976; Schroeder and Collier, 1966), diatom assemblages (Brown and Olive, 1995), fecal bacteria (Myers et al., 1998), aquatic macrophyte diversity (Balanson et al., 2005), and short-term response to dam removal (Rumschlag and Peck, 2007; Tuckerman and Zawiski, 2007). But considerably less detail is known about the loading and transport of $P$ in this effluent-affected urban stream.

Here we report results of SRP and TP as measured on water samples collected from the Cuyahoga River from July 2007 to May 2008. The results were used to indicate changes in the loadings of SRP and TP along the Cuyahoga River and its main tributary (Tinkers Creek) under three different flow conditions. We compared the riverine $P$ loadings with the effluent inputs and conducted mass-balance analyses for two river sections in the lower Cuyahoga River. Lastly, the existing long-term P loading data from the Ohio tributary monitoring program (NCWQR, 2010) were used to evaluate the role of stream flow regimes in regulating the P loading and transport in the Cuyahoga River. The main purpose of this work is to gain useful insights into the loading and transport of $P$ across the Cuyahoga River for better management practices in the basin.

\section{Study area}

The Cuyahoga River originates in its headwaters area in Geauga County (Ohio) with two branches: East Branch and West Branch (Fig. 1). The two branches join together at the southern end of Eldon Russell Park, Troy Township, Ohio. The river flows southwestward in a narrow valley toward Akron for about $70 \mathrm{~km}$, turns abruptly northward near Cuyahoga Fall, traverses a wide, deep preglacial valley in the Cuyahoga Valley National Park, and merges with Tinkers Creek before reaching Lake Erie.

The Cuyahoga River is readily divided into an upper basin of $1000 \mathrm{~km}^{2}$ above Old Portage and a lower basin of $1100 \mathrm{~km}^{2}$ above Lake Erie (NWIS, 2011). Grassland, pasture, forest and agriculture are the dominant land uses in the upper Cuyahoga River, whereas urban and residential land uses dominates in the lower Cuyahoga River and Tinkers Creek (OEPA, 2003). There are three reservoirs (East Branch Reservoir, LaDue Reservoir, and Lake Rockwell) in the upper Cuyahoga watershed (Fig. 1). Based on daily discharge records from the National Water Information System (NWIS, 2011 ) in the period of 2001-2007, the average discharge of the river increases substantially from $6.4 \mathrm{~m}^{3} / \mathrm{s}$ at Hiram Rapids to $15.6 \mathrm{~m}^{3} / \mathrm{s}$ at Old Portage to $30.8 \mathrm{~m}^{3} / \mathrm{s}$ at Independence (Table 1 ). The average precipitation is around $95 \mathrm{~cm} / \mathrm{yr}$ and the average flow yield is around $35 \mathrm{~cm} / \mathrm{yr}$ ( or $0.01 \mathrm{~m}^{3} / \mathrm{s} \mathrm{km}^{-2}$ ) across the watershed, based on daily duration curves derived from daily stream flow readings at four USGS gaging stations between 1978 and 2008 (Fig. 2a). We used the cumulative time percentage (\%) as shown in Fig. 2a to categorize three flow regimes, namely storm flow $(<5 \%)$, intermediate flow (5-60\%) and low flow (>60\%). This may better reflect the fact that the probability distribution of daily stream flow is usually skewed instead of bell-shaped,
The Cuyahoga River receives P from a variety of point and nonpoint sources. Major sources include municipal effluents, combined sewer overflows (CSO), and to a lesser extent agricultural and natural runoffs (OEPA, 1999). There are about sixteen WWTPs and industrial dischargers in the upper Cuyahoga watershed and nine WWTPs in the lower Cuyahoga watershed (seven of them in the Tinkers Creek watershed) (Table 2; OEPA, 2003). Most of these WWTPs are relatively small and release effluent at a flow rate of below $0.22 \mathrm{~m}^{3} / \mathrm{s}$. The Akron Water Pollution Control Station (AWPCS) serves a population of 330,000 in the city of Akron and its neighboring communities and releases effluent into the lower Cuyahoga River within reach $A$ at an average discharge rate of $3.42 \mathrm{~m}^{3} / \mathrm{s}$ (Fig. 1). The Cleveland Southerly Wastewater Treatment Plant (CSWTP) serves a population of 601,000 in the Greater Cleveland area and emits effluent into the river within reach $B$ with an average rate of $5.48 \mathrm{~m}^{3} / \mathrm{s}$.

The stream water chemistry changes greatly in the Cuyahoga River from the headwaters downstream. $\mathrm{Ca}^{2+}, \mathrm{Na}^{+}$, and $\mathrm{HCO}_{3}^{-}$dominate in water of the upper Cuyahoga River while $\mathrm{Na}^{+}, \mathrm{Cl}^{-}$and $\mathrm{HCO}_{3}^{-}$dominate in water of the lower Cuyahoga River (Table 1). The concentration of total dissolved solids (TDS) of the river increases significantly from $255 \mathrm{mg} / \mathrm{l}$ at Hiram Rapids to $609 \mathrm{mg} / \mathrm{l}$ at Independence though the discharge of stream flow increases fourfold. As a result, the average TDS loading of river water increases over tenfold from $51.5 \times 10^{3} \mathrm{Mg} / \mathrm{yr}$ at Hiram Rapids to $592 \times 10^{3} \mathrm{Mg} / \mathrm{yr}$ at Independence. The major ion chemistry of Tinkers Creek at Bedford is similar to that of the lower Cuyahoga River at Independence (Table 1).

\section{Materials and methods}

\subsection{Data acquisition}

Consideration for selection of sampling sites includes site accessibility, spatial coverage, and availability of real-time daily streamflow data. Among a dozen of water sampling sites selected, nine were along the main stem of the Cuyahoga River and three along Tinkers Creek (Fig. 1). Four sites are close to existing USGS gaging stations (Hiram Rapids, Old Portage, Bedford, and Independence). Five water sampling campaigns were carried out between 2007 and 2008 under three different flow regimes (Fig. 2a). A total of 6 water samples were taken on July 29, 2007, 12 samples on September 3, 2007, and 12 samples on October 30, 2007 under low flow conditions, 12 samples on May 23, 2008 under intermediate flow conditions, and 12 samples on March 15, 2008 under storm flow conditions across the watershed (Fig. 2 b).

Water samples were collected by hand-dipping along the river shore at a water depth of $10-15 \mathrm{~cm}$ where flowing water was present, using $500 \mathrm{ml}$ high-density polyethylene (HDPE) wide-mouth round bottles. Prior to sampling, HDPE bottles were treated with 1.2 $\mathrm{M} \mathrm{HCl}$ solution, washed with tap and deionized water at least three times, and re-washed three times in situ using river water. Water samples were frozen and shipped to the National Center for Water Quality Research (NCWQR) at Heidelberg University in Ohio. Analyses of SRP and TP were carried out at the NCWQR by semi-automated colorimetry (version II) in accordance with the U.S. EPA SW-846 Solid Waste method procedures. The method detection limits (MDL) of TP and SRP were determined as 2.3 and $0.8 \mu \mathrm{g} / \mathrm{l}$, respectively.

Additionally, existing data of stream and effluent flows were gathered from different agencies. Daily stream discharge data of the Cuyahoga River at the four USGS gaging stations (Hiram Rapids, Old Portage, Bedford, and Independence) were downloaded from the National Water Information System (NWIS, 2011). Daily effluent discharge data were provided by the two major WWTPs (i.e., 


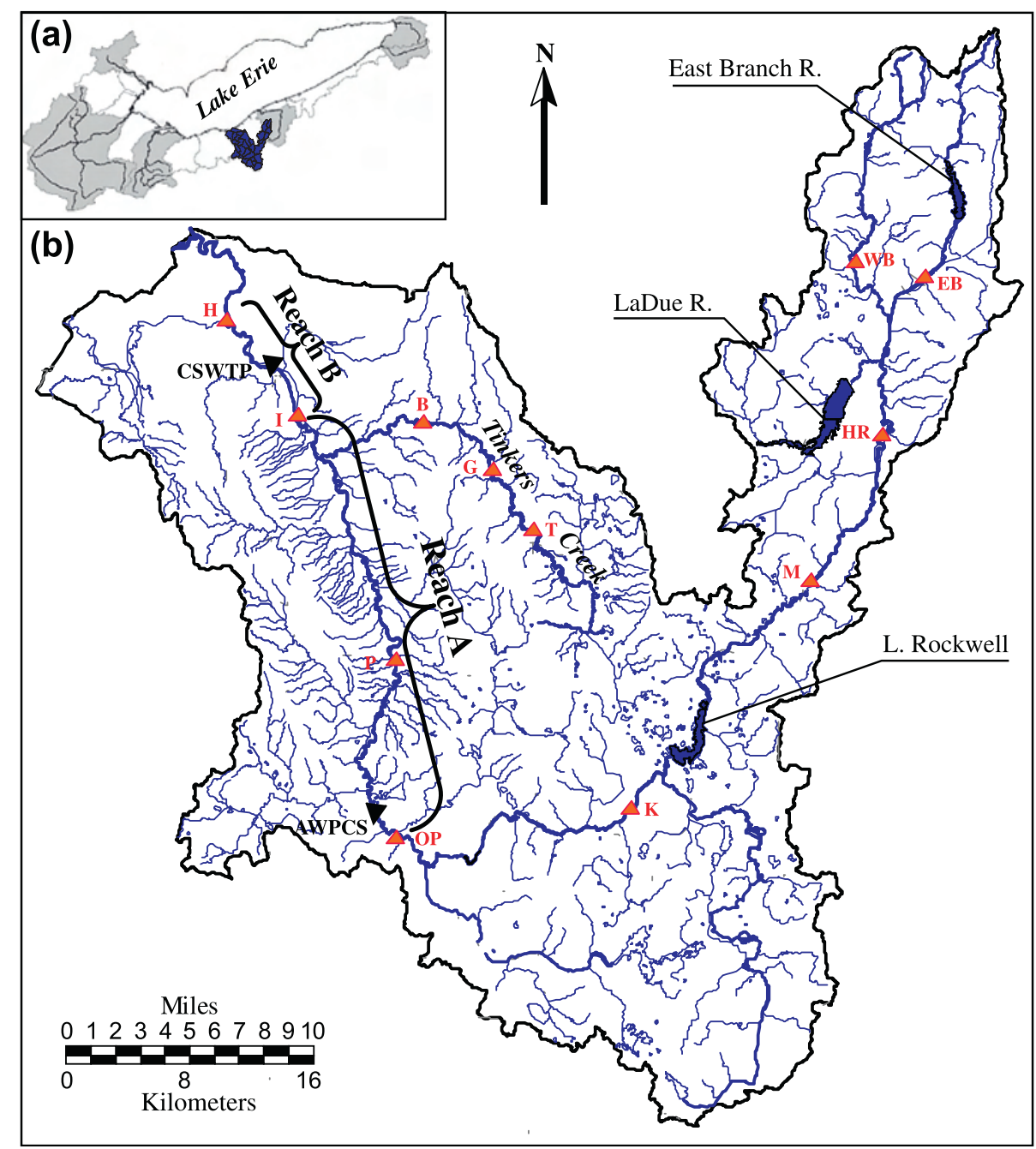

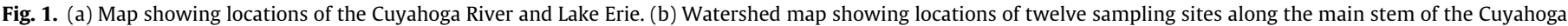

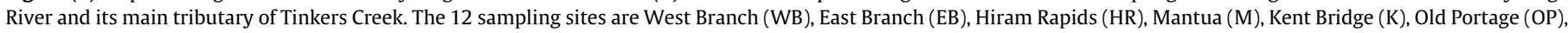

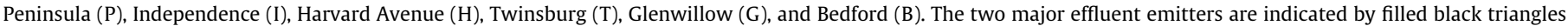
namely the Akron Water Pollution Control Station (AWPCS) in reach A and Cleveland Southerly Wastewater Treatment Plants (CSWTP) in reach B.

Table 1

Mean flow and major ion concentrations of surface waters in the Cuyahoga River and Tinkers Creek between 2001 and $2007 .{ }^{a}$

\begin{tabular}{|c|c|c|c|c|c|c|c|c|c|c|}
\hline Gaging station & $\begin{array}{l}\text { Flow } \\
\left(\mathrm{m}^{3} / \mathrm{s}\right)\end{array}$ & $\begin{array}{l}\mathrm{pH} \\
\text { (S.U.) }\end{array}$ & $\begin{array}{l}\mathrm{Ca} \\
(\mathrm{mg} / \mathrm{l})\end{array}$ & $\begin{array}{l}\mathrm{Mg} \\
(\mathrm{mg} / \mathrm{l})\end{array}$ & $\begin{array}{l}\mathrm{Na} \\
(\mathrm{mg} / \mathrm{l})\end{array}$ & $\begin{array}{l}\mathrm{K} \\
(\mathrm{mg} / \mathrm{l})\end{array}$ & $\begin{array}{l}\mathrm{HCO}_{3} \\
(\mathrm{mg} / \mathrm{l})\end{array}$ & $\begin{array}{l}\mathrm{SO}_{4} \\
(\mathrm{mg} / \mathrm{l})\end{array}$ & $\begin{array}{l}\mathrm{Cl} \\
(\mathrm{mg} / \mathrm{l})\end{array}$ & $\begin{array}{l}\text { TDS } \\
(\mathrm{mg} / \mathrm{l})\end{array}$ \\
\hline \multicolumn{11}{|l|}{ Cuyahoga River } \\
\hline Hiram Rapids & 6.4 & 7.9 & 34 & 7.8 & 28 & 2.2 & 104 & 28 & 43 & 255 \\
\hline Old Portage & 15.6 & 8.0 & 59 & 14 & 58 & 4.0 & 149 & 56 & 103 & 451 \\
\hline Independence & 30.8 & 8.0 & 67 & 15 & 111 & 5.2 & 153 & 72 & 178 & 609 \\
\hline \multicolumn{11}{|l|}{ Tinkers Creek } \\
\hline Bedford & 4.3 & 7.9 & 56 & 13 & 117 & 6.8 & 140 & 61 & 194 & 596 \\
\hline
\end{tabular}

a Original flow data were taken from USGS National Water Information System (NWIS) and water quality data from USEPA STORET.

AWPCS and CSWTP). Lastly, we retrieved long-term TP and SRP records of the Cuyahoga River at Independence from the Ohio tributary monitoring program (NCWQR, 2010).

\subsection{Loading calculations}

In theory, the instantaneous loading $\left(L_{i}\right.$, in $\left.\mathrm{g} / \mathrm{s}\right)$ of the river at a specific monitoring station is a function of time ( $t$, in $s)$ and equals to the product of the instantaneous concentration $(C$, in $\mathrm{mg} / \mathrm{l})$ and river discharge $\left(Q\right.$ in $\left.\mathrm{m}^{3} / \mathrm{s}\right)$, as expressed by
$L_{i}=f(t)=C(t) Q(t)$

where $C(t)$ and $Q(t)$ are the instantaneous concentration and river discharge at time $t$. Since the instantaneous P loading is quite variable, it is always desirable to know the average flux (or loading) of $\mathrm{P}$ traveling through a monitoring station in a specific time interval $\left(\Delta t=t_{2}-t_{1}\right)$. The average loading $(\bar{L})$ of the river at a given monitoring station in a time interval of $\Delta t$ can be estimated by

$\bar{L}=\frac{\int_{t_{1}}^{t_{2}} f(t) d t}{t_{2}-t_{1}}$ 

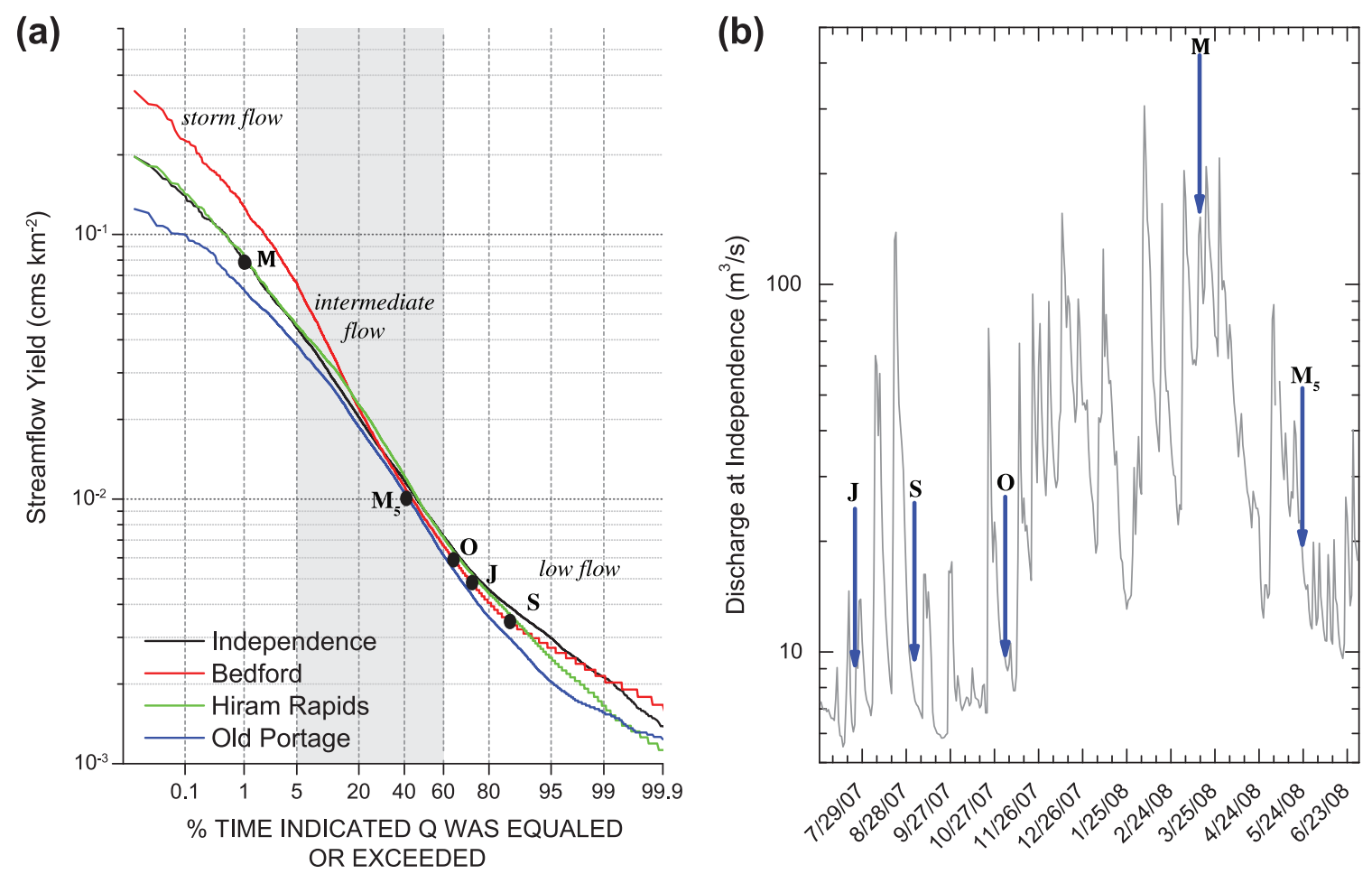

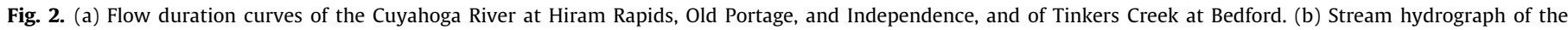

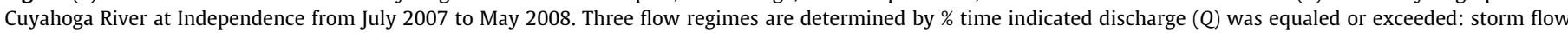

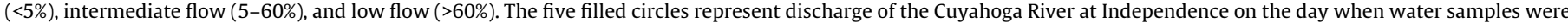
taken. M - March15, 2008; M $_{5}$ - May 23, 2008; J - July 29, 2007; S - September 3, 2007; O - October 30, 2007.

Table 2

Estimated P loading from known point sources in Cuyahoga watersheds. ${ }^{\mathrm{a}}$

\begin{tabular}{|c|c|c|c|c|c|}
\hline \multirow[t]{2}{*}{ Facility name } & \multicolumn{3}{|c|}{ Average discharge } & \multirow{2}{*}{$\begin{array}{l}\text { TP } \\
(\mathrm{mg} / \mathrm{l})\end{array}$} & \multirow{2}{*}{$\begin{array}{l}\text { TP load } \\
\text { (Mg/yr) }\end{array}$} \\
\hline & $\mathrm{MGD}^{\mathrm{b}}$ & $\left(\mathrm{m}^{3} / \mathrm{s}\right)$ & $\left(\mathrm{km}^{3} / \mathrm{yr}\right)$ & & \\
\hline \multicolumn{6}{|l|}{ Cuyahoga River near Kent, Ohio } \\
\hline Twin Lakes WWTP & 0.5 & 0.02 & 0.001 & 1.0 & 0.7 \\
\hline Akron WTP & 1.6 & 0.07 & 0.002 & 1.0 & 2.2 \\
\hline Ravenna WWTP & 2.8 & 0.12 & 0.004 & 1.0 & 3.9 \\
\hline Franklin Hills WWTP & 2.0 & 0.09 & 0.003 & 1.0 & 2.8 \\
\hline Kent WWTP & 5.0 & 0.22 & 0.007 & 1.0 & 6.9 \\
\hline Fish Creek WWTP & 5.0 & 0.22 & 0.007 & 1.0 & 6.9 \\
\hline Akron Water Pollution Control Station (AWPCS) & 78.6 & 3.44 & 0.109 & 0.7 & 73.8 \\
\hline \multicolumn{6}{|l|}{ Tinkers Creek area } \\
\hline Aurora Westerly Plant & 1.4 & 0.06 & 0.002 & 1.0 & 1.9 \\
\hline Bedford WWTP & 3.2 & 0.14 & 0.004 & 1.0 & 4.4 \\
\hline Bedford Heights WWTP & 7.5 & 0.33 & 0.010 & 1.0 & 10.4 \\
\hline Streetsboro WWTP & 4.0 & 0.18 & 0.006 & 1.0 & 5.5 \\
\hline Solon WWTP & 5.8 & 0.25 & 0.008 & 1.0 & 8.0 \\
\hline Twinsburg WWTP & 3.4 & 0.15 & 0.005 & 1.0 & 4.7 \\
\hline Southerly Wastewater Treatment Plant (CSWTP) & 125 & 5.48 & 0.173 & 0.5 & 86.3 \\
\hline Total & 245.8 & 10.8 & 0.340 & & 218.4 \\
\hline
\end{tabular}

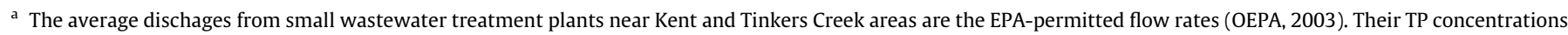
are assumed to be $1.0 \mathrm{mg} / \mathrm{L}$.

b MGD: Million gallon per day.

In reality, the yearly loading ( $\bar{L}_{a}$, in metric tons or $\mathrm{Mg} / \mathrm{yr}$ ) of SRP or TP in a river can be estimated as follows (Baker, 2005).

$\bar{L}_{a}=\gamma \frac{\Sigma t_{j} C_{j} Q_{j}}{\Sigma t_{j}}$

where $Q_{j}$ is the average river discharge in the sampling interval (in $\left.\mathrm{m}^{3} / \mathrm{s}\right), C_{j}$ is the concentration of SRP or TP in the composite water sample collected during the sampling interval (in $\mathrm{mg} / \mathrm{l}$ ), $t_{j}$ is the time interval (in days) of the composite sample, and $\gamma=31.536$, is a $\mathrm{g} / \mathrm{s}$ to $\mathrm{Mg} / \mathrm{yr}$ unit conversion coefficient.

Alternatively, the average loading $(\bar{L})$ can be approximated by the arithmetic mean of the instantaneous loadings $\left(L_{i}\right)$.

$\bar{L}=\frac{\Sigma L_{i}}{n}=\frac{\Sigma C_{i} Q_{i}}{n}=\bar{C} \bar{Q}$

where $n$ is the number of the instantaneous loadings measured, $\bar{C}$ is the flow-weighted average concentration, and $\bar{Q}$ is the average discharge of the river in a given time period. $\bar{L}$ may be estimated at 
three different time scales, namely daily, monthly, and yearly. The yearly average loading equals to the product of the monthly flowweighted average concentration and discharge while the monthly average loading equals to the product of the daily flow-weighted average concentration and discharge.

\subsection{Mass balances}

The mass balance is an application of the law of mass conservation to the analysis of flow and $\mathrm{P}$ loading for a river section. Changes in storage $(\Delta S)$ of a river section in a time interval $(\Delta t)$ is given by

$\frac{\Delta S}{\Delta t}=Q_{u}+\Sigma Q_{k}-Q_{d}$

where $Q_{u}, Q_{k}$, and $Q_{d}$ are the streamflow discharge in upstream, tributaries, and downstream. Accordingly, changes in the P loading $(\Delta L)$ of a given river section may be expressed as

$\Delta L=L_{u}+\Sigma L_{k}-L_{d}$

where $L_{u}, L_{k}$, and $L_{d}$ are the P loading of a given river section in upstream, tributaries, and downstream.

\section{Results}

\subsection{Riverine phosphorus loadings}

Concentrations of TP and SRP as measured on water samples collected from the river exhibit considerable variations, with values ranging from 0.030 to $0.287 \mathrm{mg} / \mathrm{l}$ in TP and from 0.004 to $0.175 \mathrm{mg} / \mathrm{l}$ in SRP (Fig. 3a and b). There is a clear distinction in the pattern of variations between the upper and lower Cuyahoga River. In the upper basin, TP and SRP were relatively low except some anomalies in the East Branch during low and intermediate flow conditions. In the lower basin (including the Tinkers Creek), however, TP and SRP increased substantially from the upstream downward under the three different flow conditions. Additionally,

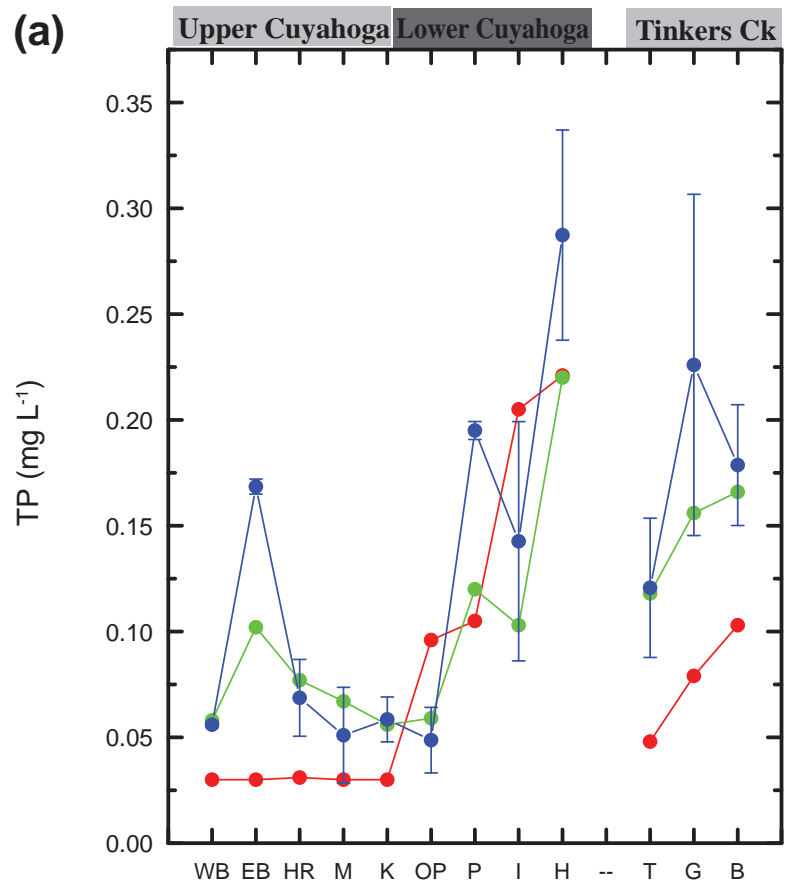

the ratio of SRP/TP increased substantially from $\sim 0.2$ in the upper Cuyahoga River to $\sim 0.7$ in the lower Cuyahoga River. Under the storm flow conditions, however, the ratio of SRP/TP was reduced to $\sim 0.1$ throughout the river basin.

The loading of TP was fairly low in the upper basin and increased rapidly in the lower basin from the upstream downward (Fig. 4a). Under the storm flow conditions, the loading of TP was extraordinarily high, which increased from $0.6 \mathrm{~g} / \mathrm{s}$ at Hiram Rapids to $4.4 \mathrm{~g} / \mathrm{s}$ at Old Portage to $36.8 \mathrm{~g} / \mathrm{s}$ at Harvard Avenue. The loading of SRP was also low $(<0.1 \mathrm{~g} / \mathrm{s})$ in the upper basin and increased rapidly in the lower basin under different flow conditions (Fig. 4b). The TP and SRP loadings of Tinkers Creek at Bedford were similar to those of the Cuyahoga River at Old Portage.

\subsection{Effluent phosphorus inputs}

Over a dozen WWTPs continuously discharge municipal effluents into the river at an average rate of $10.8 \mathrm{~m}^{3} / \mathrm{s}$ (Table 2), accounting for on average $30 \%$ of stream flow as gaged at Independence. Concentrations of the effluent TP from the AWPCS and CSWTP from 2006 to 2008 were 0.7 and $0.5 \mathrm{mg} / \mathrm{l}$, respectively (Table 3). But there were great daily variations in discharge, TP concentration, and TP loading of effluents from the AWPCS and CSWTP. For example, values of the maximal TP loading were one order of magnitude greater than those of the minimal TP loading. In contrast, variations in monthly-averaged discharge, TP concentration, and TP loading of effluents from the two WWTPs were significantly reduced. Moreover, the year-to-year changes in the TP loading of municipal effluents appeared to be minimal. For instance, the difference between maximum and minimum of yearly-averaged TP loading at the CSWTP was only $0.013 \mathrm{Mg} / \mathrm{d}$ or $5 \%$ of the mean TP loading (Table 3 ).

\subsection{Comparison of riverine and effluent phosphorus loadings}

Values of the effluent TP loading from the AWPCS and CSWTP were comparable to those of the riverine TP loading downstream

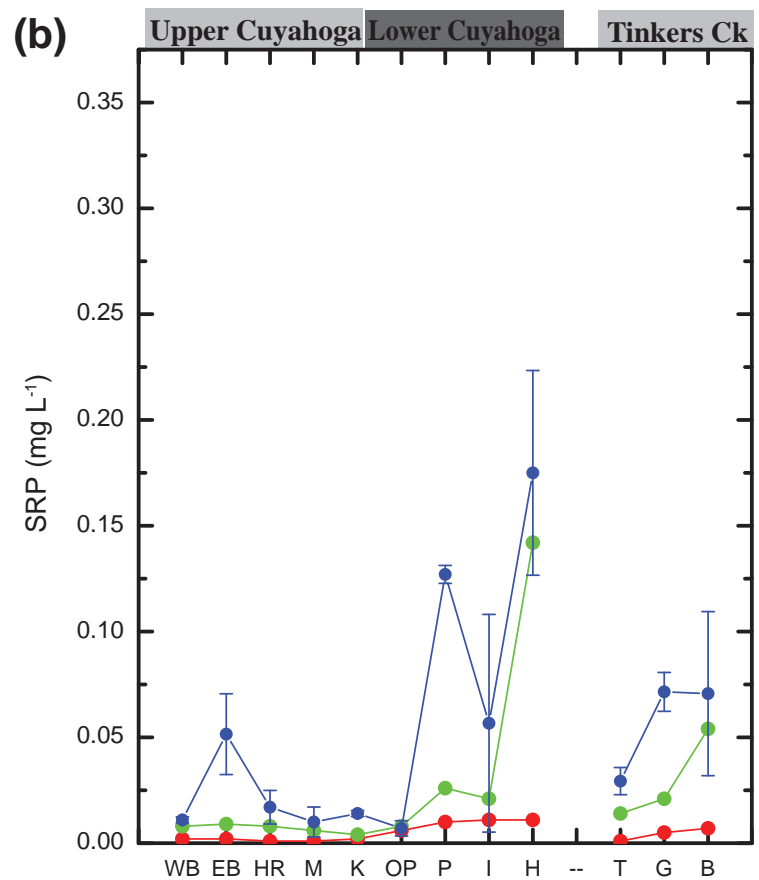

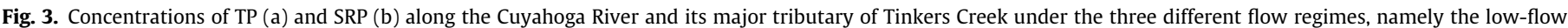

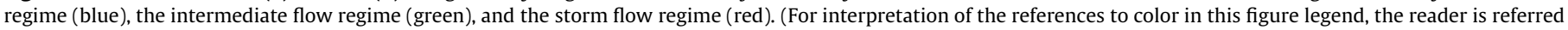
to the web version of this article.) 

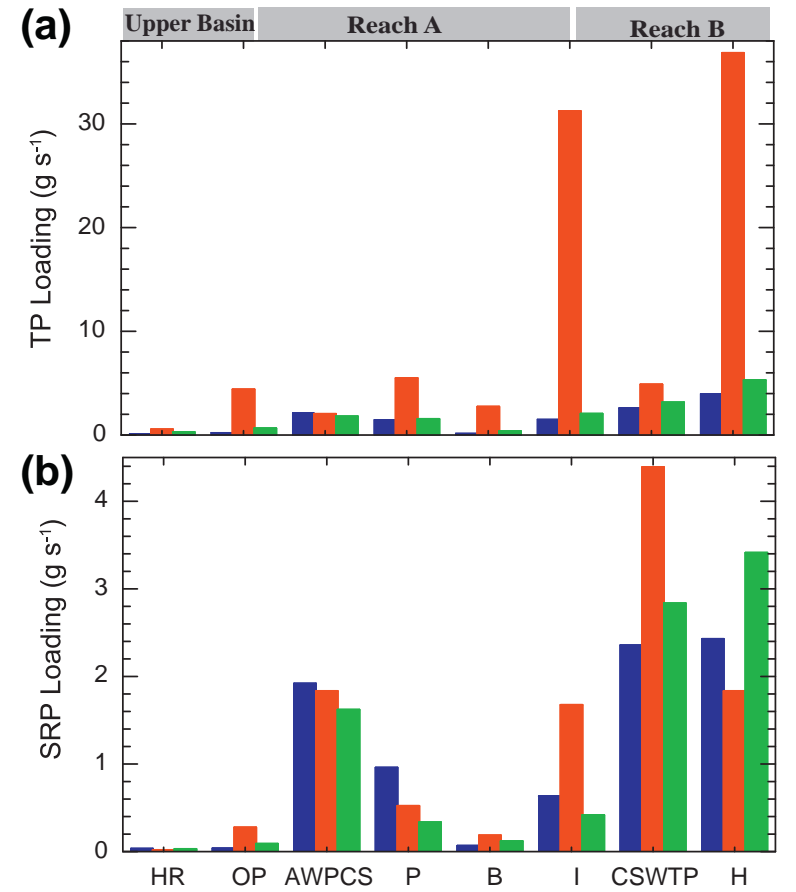

Fig. 4. Loadings of TP (a) and SRP (b) at selected stations and the two major effluent emitters under the three different flow regimes, namely the low-flow regime (blue), the intermediate flow regime (green), and the storm flow regime (red). HR - Hiram Rapids; OP - Old Portage; I - Independence; B - Bedford. (For interpretation of the references to color in this figure legend, the reader is referred to the web version of this article.)

under the low and intermediate flow conditions (Fig. 4a). As noted above, values of the riverine TP loading under the storm flow conditions were extremely high and far exceeded those of the effluent TP loading upstream. On the other hand, values of the effluent SRP loading from the two WWTPs were overall larger than those of the riverine SRP loading downstream (Fig. 4b).

Comparison of the monthly-averaged TP loading from the AWPCS with the riverine SRP loading at Independence during a period of 2006-2008 reveals some interesting features (Fig. 5). First, the average value of the effluent TP loading was $0.20 \mathrm{Mg} / \mathrm{d}$, much larger than that of the riverine SRP loading as gaged at Independence $(0.12 \mathrm{Mg} / \mathrm{d})$. Second, there was a great deal of similarity between the two records, indicating a great influence of effluent $P$ inputs. Third, there existed some important discrepancies. For example, the moderate TP loading from the AWPCS in December 2007 was apparently inconsistent with the greatest value of the monthly-averaged SRP loading observed at Independence. The effluent TP loading was near or above the average from March to

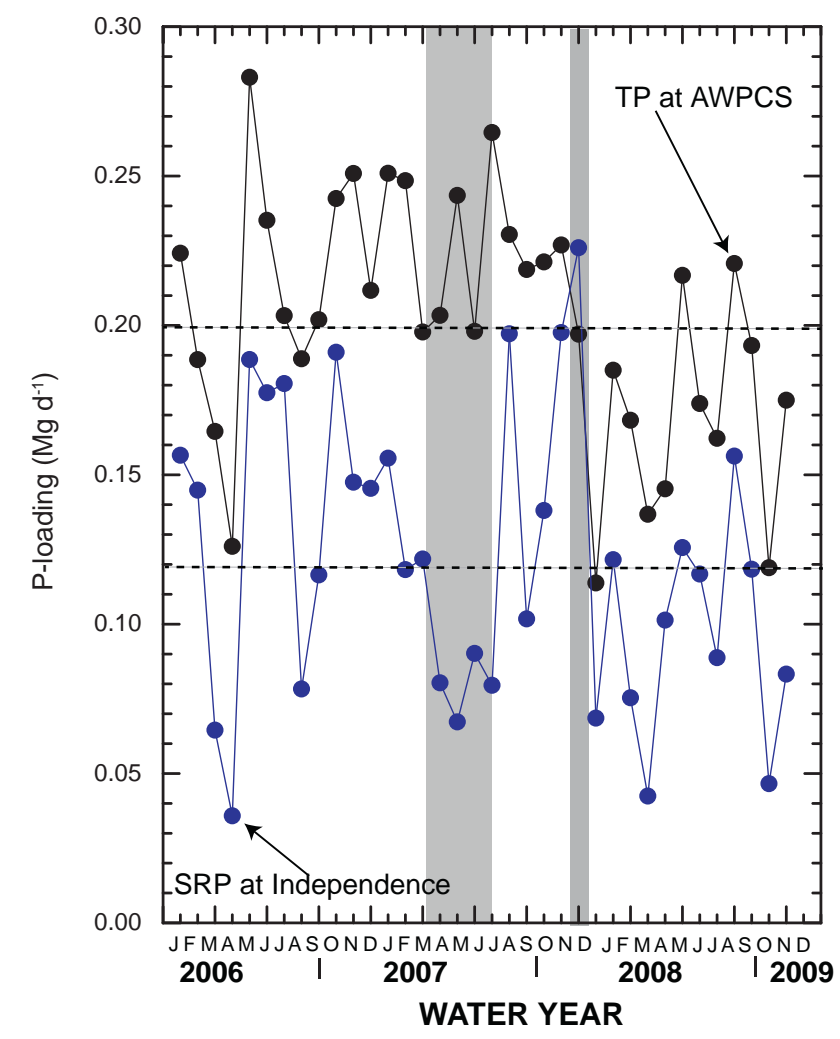

Fig. 5. Comparison of the TP loading from Akron Water Pollution Control Station (AWPCS) with the SRP loading record of the Cuyahoga River at Independence. Vertical gray bars highlight periods with inconsistent loadings as discussed in the text. Horizontal dashed lines represent the mean loading values of TP and SRP.

July 2007, whereas the concurrent riverine SRP loading at Independence was far below the average.

\subsection{Mass balance analyses of phosphorus loading}

Two river reaches (A and $B$ ) were selected for mass balances. Reach A stretches from Old Portage to Independence, with a river length of $43.5 \mathrm{~km}$ (Fig. 1). It receives effluent from the AWPCS and stream water upstream gaged at Old Portage, and tributary flow from Tinkers Creek gaged at Bedford and many other ungagged small creeks. The ungagged flow ranged from $14 \%$ of the stream flow gaged at Independence under the low flow conditions to $48 \%$ under the storm flow conditions (Table 4 ). Although a fair amount of stream flow was ungaged and excluded for the massbalance analysis, the loading of SRP observed at Independence

Table 3

Summary of discharge, TP, and TP loading from two major wastewater treatment plants. ${ }^{a}$

\begin{tabular}{|c|c|c|c|c|c|c|c|c|c|}
\hline & \multicolumn{3}{|c|}{ Discharge (MGD) } & \multicolumn{3}{|c|}{$\mathrm{TP}(\mathrm{mg} / \mathrm{l})$} & \multicolumn{3}{|c|}{ TP loading (Mg/d) } \\
\hline & Mean & Max & Min & Mean & Max & Min & Mean & Max & Min \\
\hline \multicolumn{10}{|c|}{ Akron water polution control station } \\
\hline Daily & 78.2 & 232.4 & 49.2 & 0.698 & 1.920 & 0.220 & 0.202 & 0.928 & 0.062 \\
\hline Monthly & 77.8 & 134.5 & 55.8 & 0.701 & 0.915 & 0.330 & 0.201 & 0.283 & 0.114 \\
\hline Yearly & 77.8 & 80.3 & 74.9 & 0.701 & 0.764 & 0.738 & 0.201 & 0.223 & 0.167 \\
\hline \multicolumn{10}{|c|}{ Cleveland southerly wastewater treatment plant } \\
\hline Daily & 125.5 & 380.5 & 69.4 & 0.533 & 1.200 & 0.060 & 0.237 & 0.817 & 0.029 \\
\hline Monthly & 125.8 & 218.9 & 80.7 & 0.514 & 0.772 & 0.203 & 0.237 & 0.320 & 0.115 \\
\hline Yearly & 125.8 & 128.4 & 124.0 & 0.514 & 0.523 & 0.499 & 0.237 & 0.245 & 0.232 \\
\hline
\end{tabular}

a Derived from daily monitoring data during the 3-year period (2006-2008) at the two WWTPs. 


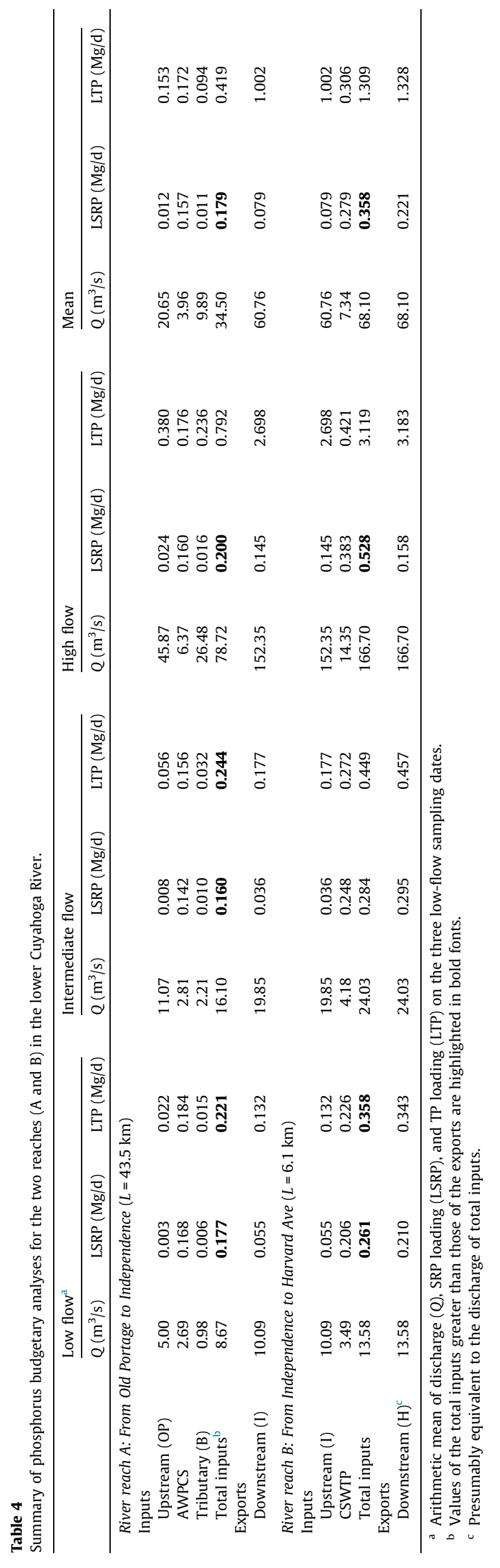

was 44\% lower than the total inputs of SRP from the three known sources (upstream at Old Portage, AWPCS, and Tinkers Creek at Bedford) under the three different flow conditions. There were varying degrees (27-77\%) of loss in the SRP loading in this reach. On the other hand, the riverine loading of TP observed at Independence was lower than the amount of the total inputs during the low and intermediate flow events but was three times larger than the amount of the total inputs during the storm flow event. Reach $B$, a relatively short $(6.1 \mathrm{~km})$ section between Independence and Harvard Ave (Fig. 1), receives effluent from the CSWTP, discharge from upstream gaged at Independence, and stream flows from three ungaged tributaries (West Creek, Mill Creek, and Big Creek). Compared to the magnitude of the two contributors, inputs from the ungagged tributaries are negligible. The loading of TP was more or less balanced under the three different flow conditions, whereas the loading of SRP at Harvard Avenue was on average 38\% less than that of the total inputs of SRP from CSWTP and upstream at Independence. In summary, losses of the loading of SRP in the lower Cuyahoga River occurred on most occasions while the loading of TP could increase substantially during storm events. The amount of gain in the TP loading was closely related to the amount of loss in the TP loading during the low and intermediate flow periods.

\section{Discussion}

We found multiple lines of evidence indicating that the P loading in the Cuyahoga River came largely from effluent inputs. First, the riverine $\mathrm{P}$ loading increased rapidly downstream due to increases in municipal effluents in the lower Cuyahoga River. Second, the ratio of SRP/TP of the Cuyahoga River increased substantially from the upper to lower basin. Third, we found the amount of the effluent TP input was comparable to that of the riverine TP loading, particularly under the low and intermediate flow conditions. Lastly, there was a great deal of similarity between the effluent TP loading record from the AWPCS and the riverine SRP loading record from the Cuyahoga River at Independence. We thus concluded that the lower Cuyahoga River suffered from excessive nutrient loadings from municipal effluents, a conclusion in agreement with the indices of biotic integrity and water quality (OEPA, 1999).

Furthermore, we found that effluent P was highly active and subject to rapid changes or transformations in the Cuyahoga River and that changes in the riverine P loading were affected by streamflow conditions. Comparison of the effluent P loading record from the AWPCS and the riverine SRP loading record indicated that between 2006 and 2009 the average SRP loading of the Cuyahoga River as gaged at Independence was only $60 \%$ of the effluent P input, suggesting $30-40 \%$ of the reactive effluent $\mathrm{P}$ was converted to other forms in this river section. This notion is in line with our mass-balance analyses indicating that $27-77 \%$ of the total SRP inputs were lost in reach $\mathrm{A}$. We also noted that this river section retained a fair amount of TP under the low and intermediate flow conditions and released the retained TP during the storm flow conditions, highlighting the role of flow regimes in regulating the $\mathrm{P}$ loading and transport across the river.

To address the influence of streamflow conditions, we used the existing long-term tributary monitoring data of the Cuyahoga River at Independence (NCWQR, 2010) to examine the changes in the P loading and transport in relation to hydrological variability in the river on different timescales. As shown in Fig. 6, the concentration of TP increased concurrently with increasing stream discharge during the two consecutive storm events occurred in August 2008. The concurrent increases in the riverine TP also seen in agriculturaldominated watersheds were attributed to increases in P-bearing suspended sediments during storm events (Richards et al., 2001). 


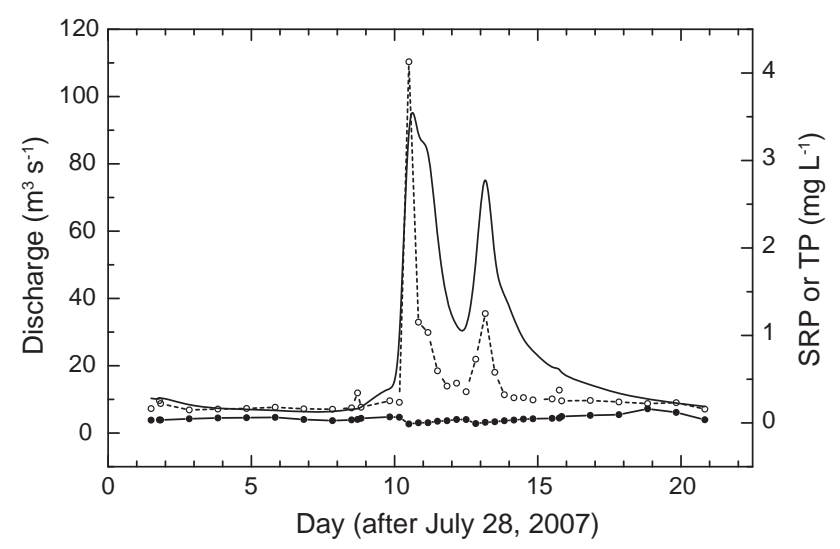

Fig. 6. Variations in stream discharge (solid line), SRP (filled circles) and TP (open circles) concentrations of the Cuyahoga River at Independence before and during two consecutive storm events in August 2007.

On the other hand, the concentration of SRP decreased slightly during the storm events (Fig. 6), presumably attributed to the dilution effect of storm water. But the results from mass-balance analysis show that there was an up to $70 \%$ loss of the SRP loading during the storm flow events (Table 4), indicating that the riverine P transformations (e.g., adsorption) were active in the lower Cuyahoga River. It has been repeatedly documented that $\mathrm{P}$ released from
WWTPs interacts quickly with stream water, sediments, and aquatic communities (e.g., algae, phytoplankton and macrophytes) through a range of physical and biological processes (House, 2003; Marti et al., 2004; Withers and Jarvie, 2008). The degree of the interactions is highly variable, depending on the $\mathrm{P}$ retention capacity, saturation rate, and effluent inputs. For instance, the rates of $P$ retention were reported to vary from below $10 \%$ to over $30 \%$ under a range of flow conditions in the River Swale, northern England (House, 2003) and reach up to $60 \%$ under low flow conditions in the River Kennet, England (Jarvie et al., 2002). As to the Cuyahoga River, much uncertainty remains in the dominant processes controlling the quantitative relationship between $P$ retention and stream flow. Nevertheless, our results are broadly consistent with these studies in indicating that riverine retention and processing can lead to changes in the form, quantity, and timing of P transported downstream (Withers and Jarvie, 2008).

Richards et al. (2001) estimated that over $90 \%$ of the suspended solids loading in the Maumee and Sandusky Rivers was transported during storm runoff periods which normally accounted for less than a third of the total time. Based on the daily discharge readings from the USGS database (NWIS, 2011) and the daily and sub-daily sampled TP and SRP concentration data of the Cuyahoga River at Independence between 1982 and 2009 (NCWQR, 2010), the percentages of time, discharge, SRP loading, and TP loading were used to evaluate the relative importance of each flow regime. The Cuyahoga River delivered, on average, $53 \%$ of river water under the intermediate flow conditions, $27 \%$ of river water under the low
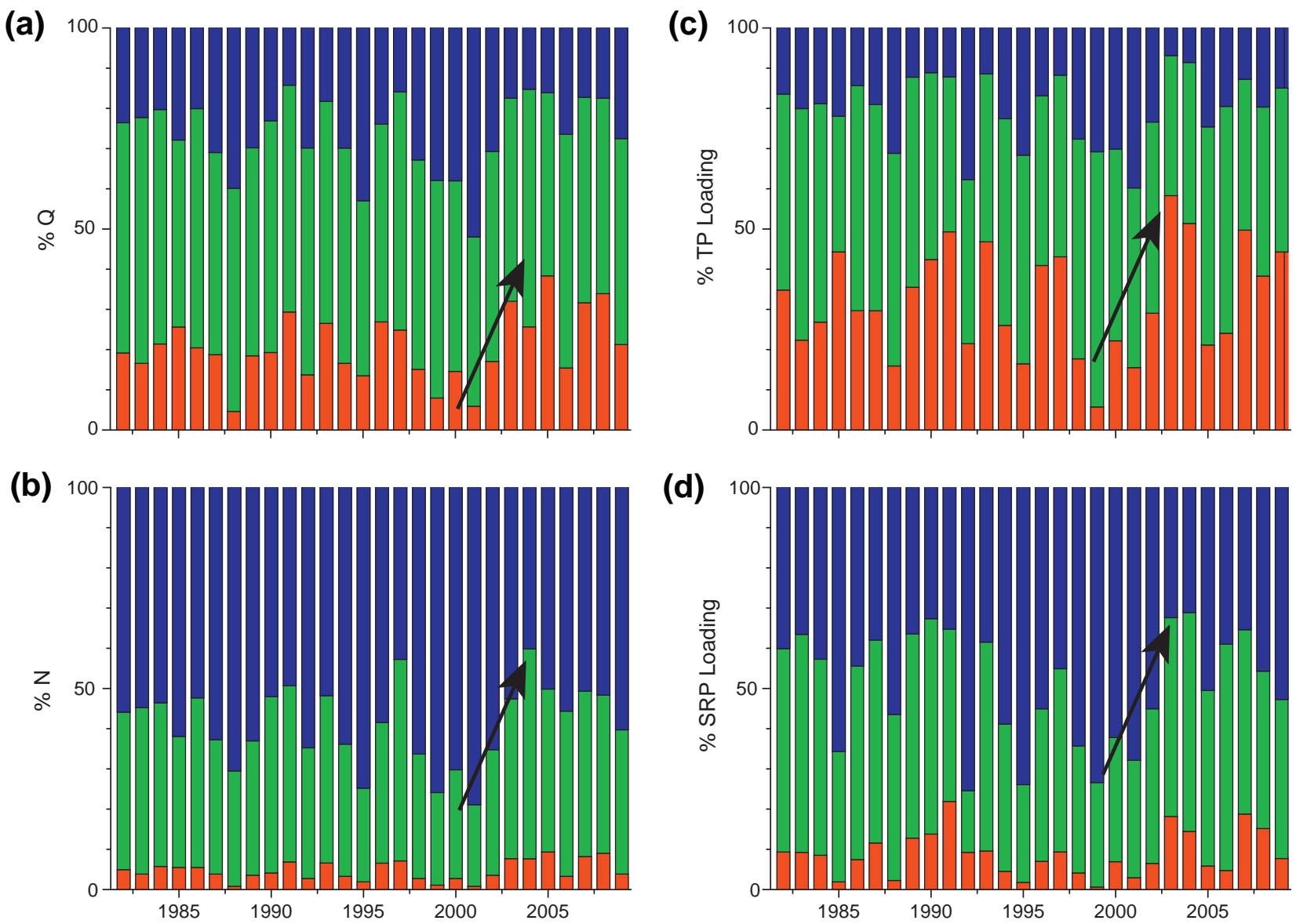

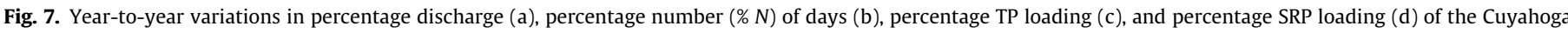

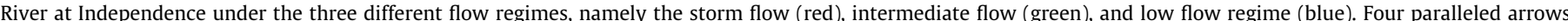

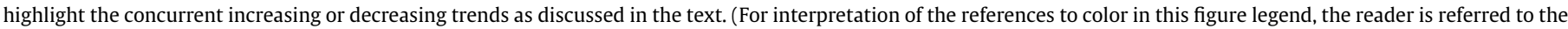
web version of this article.) 


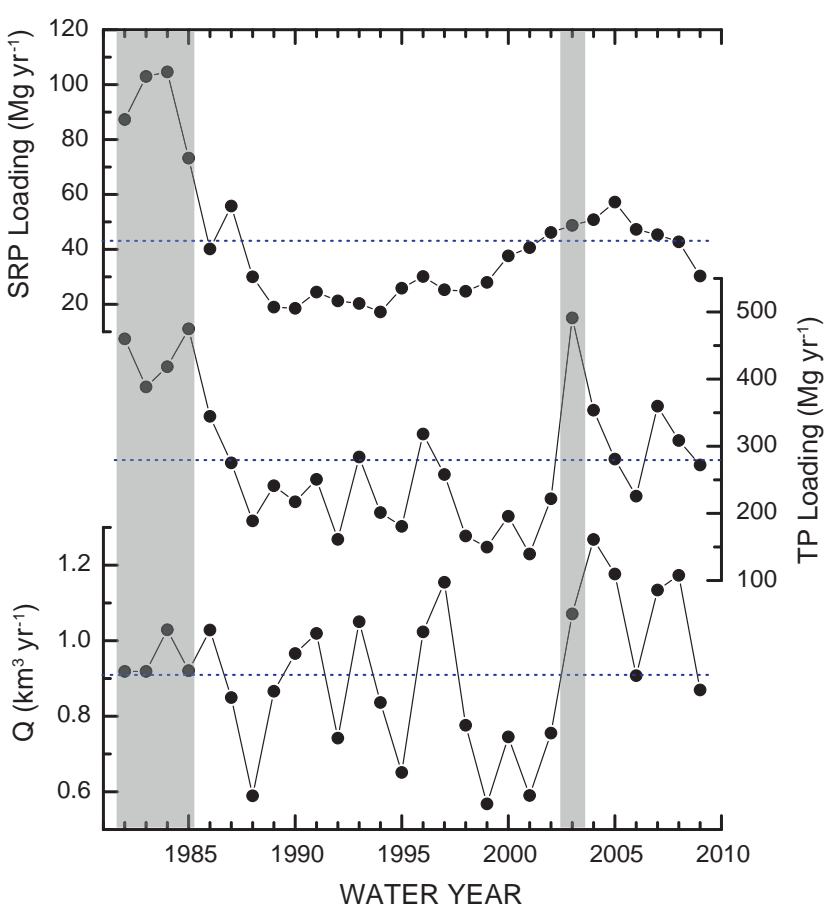

Fig. 8. Year-to-year changes in stream discharge $(Q)$, TP loading, and SRP loading of the Cuyahoga River near Independence from 1982 to 2009. Horizontal dashed lines represent the long-term mean values of $Q$ TP loading, and SRP loading. Vertical bars highlight periods with extraordinarily large TP loading.

flow conditions, and $20 \%$ of river water under the storm flow conditions even though storm runoff periods account for less than $5 \%$ of the total time (Fig. $7 \mathrm{a}$ and b). $80 \%$ of the TP loading was delivered during the storm and intermediate flow periods, whereas $91 \%$ of the SRP loading was transported during the low and intermediate flow periods (Fig. 7c and d). Furthermore, there were great year-toyear variations in the percentage of the P loading during the low flow periods. For instance, the low-flow SRP loading percentages were below 40\% between 1989 and 1991 and increased abruptly to 75\% in 1992 (Fig. 7d). Most of the high low-flow SRP loading percentages coincided with the low-flow years such as 1988, 1992, 1995, 1998-2002 (Fig. 8). In contrast, the high-flow TP loading percentage was about 5\% in 1999 and increased progressively to about $60 \%$ in 2003 (Fig. 7c). As highlighted by upward paralleled arrows in Fig. 7, the increasing trends of the high-flow discharge and TP loading percentages from 1999 to 2003 were concurrent with the decreasing trends of the low-flow time and SRP loading percentages. The observed changes in the SRP and TP loading percentages further attest to the importance of stream hydrology in regulating the $\mathrm{P}$ loading and transport in this effluent-affected urban watershed.

Analyses of long-term (multidecadal) monitoring data can help develop a useful context of changes in stream chemistry (Yuan and Miyamoto, 2004; Yuan et al., 2007), effectiveness of nutrient management (Bowes et al., 2011; Gustafsson et al., 2012; Howden and Burt, 2008), and trends in suspended sediment and SRP loadings (Daloğlu et al., 2012; Richards et al., 2008). We examined the year-to-year changes in the loadings of TP and SRP in relation to changes in streamflow discharge, using the long-term tributary monitoring data of the Cuyahoga River at Independence for water years from 1982 to 2009 (NCWQR, 2010). There were great variations in the annual loadings, with SRP loading ranging from 20 to $105 \mathrm{Mg} / \mathrm{yr}$ and TP loading from 150 to $500 \mathrm{Mg} / \mathrm{yr}$ (Fig. 8). The loadings of TP and SRP were extraordinarily large between 1982 and 1985, reflecting the historical P loadings prior to the implementa-

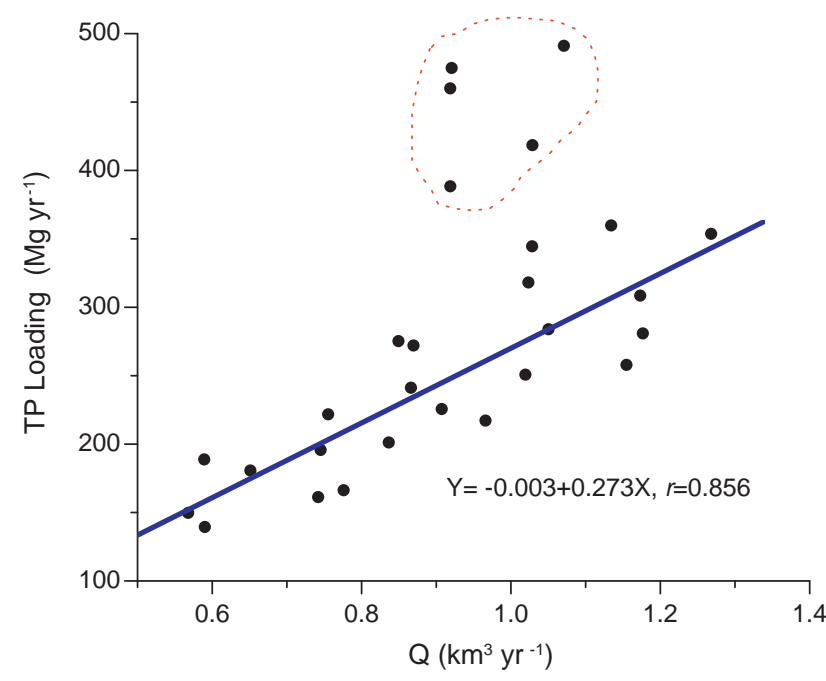

Fig. 9. Linear regression of the annual stream discharge $(Q)$ and TP loading of the Cuyahoga River at Independence. Points within the dashed line represent years with extraordinarily large TP loading as highlighted in Fig. 8.

tion of stringent $\mathrm{P}$ regulations, such as the phosphate detergent ban and $1 \mathrm{mg} / \mathrm{l}$ effluent P standard (Hartig et al., 1990). The largest loading of TP occurred in 2003, most likely attributed to low flow conditions in the preceding five consecutive years (1998-2002). There was a robust correlation $(r=0.86)$ between the annual discharge and loading of TP in the Cuyahoga River except the above-mentioned five years $(1982-85,2003)$ with extraordinarily large loading of TP as enclosed by the dashed line in Fig. 9. This is due in part to that the annual effluent loading is more or less constant. As a result, variations in streamflow discharge are the dominant driver that regulates the annual TP loading of the river.

On the other hand, the annual loading of SRP generally followed the decreasing trend of the TP loading from 1985 to 1989 as a result of the stringent P regulations (Hartig et al., 1990). The loading of SRP remained its minima until 1994, then increased progressively to the maxima in 2005, and declined from 2005 to 2009. It is worth noting that the increasing trend of the SRP loading from 1995 to 2005 was also observed in other watersheds of the Lake Erie basin (Baker, 2007; OEPA, 2010), coinciding with the recent resurge of harmful algal blooms in Lake Erie (Conroy et al., 2005; Michalak et al., 2013). Comparison of the riverine SRP loading with the discharge record revealed there were some degrees of covariability, particularly in the period between 1995 and 2009. This observation suggests that the basin-wide changes in the tributary loading of SRP are related to variations in hydroclimate, e.g., recent increases in storm events across the region (Daloğlu et al., 2012).

While the results of this study may contribute to the ongoing efforts to unravel the causes for the resurge of harmful algal blooms in Lake Erie, some uncertainty regarding the tributary $P$ loading and transport still remains. First, our estimated average values of the SRP and TP loadings from our analytical results are comparable to those from the daily to sub-daily resolved samples (Baker, 2007). Our estimated mean loading of TP between 2007 and 2008 was $365 \mathrm{Mg} / \mathrm{yr}$ (or $1.002 \mathrm{Mg} / \mathrm{d}$ in Table 4), close to the average value of $350 \mathrm{Mg} / \mathrm{yr}$ from the long-term tributary monitoring data (Fig. 8), while our estimated mean loading of SRP between 2007 and 2008 was $29 \mathrm{Mg} / \mathrm{yr}$ (or $0.079 \mathrm{Mg} / \mathrm{d}$ in Table 4), 25\% lower than the average value of $42 \mathrm{Mg} / \mathrm{yr}$ as derived from the long-term tributary monitoring data (Fig. 8). Concentrations of SRP and TP are highly variable, particularly during storm flow events (Richards et al., 2001). Thus, an extensive sampling scheme would help eliminate some of the uncertainty. Second, our results revealed the 
presence of $\mathrm{P}$ transformations but less detail has been explored to evaluate the relative importance of each of the major biogeochemical processes. Lastly, we had to admit the complexity of the watershed. As described above, the Cuyahoga River also receives $\mathrm{P}$ inputs from some diffuse sources such as agricultural runoffs and combined sewer overflows (OEPA, 2003). Changes in the P loading from these sources could affect the tributary loading into Lake Erie. But the magnitude of such changes remains uncertain.

\section{Conclusions}

This study dealt with a temperate urban river ecosystem to develop a context of P loading and transport in the Cuyahoga River under the three different flow regimes. Although its stream discharge and TP loading changed from reach to reach and from time to time, the river delivered on average nearly $1 \mathrm{~km}^{3}$ of river water and over $300 \mathrm{Mg}$ of TP loading into Lake Erie annually. About 30\% of river water was municipal effluent from over a dozen WWTPs across the watershed, contributing at least two thirds of the TP loading present in the lower Cuyahoga River. We found that the loading and transport of TP and SRP were not only affected by the amount of $P$ released from the municipal effluent but also regulated by stream flow regimes. Effluent $P$ was highly reactive and subject to rapid transformations in the river. We found that losses of the loading of SRP in the lower Cuyahoga River occurred most of the sampling occasions but the loading of TP increased substantially in reach A during the storm flow event. The increases in the riverine TP loading appeared to depend on the amount of loss in the TP loading during the low and intermediate flow periods. As a result, most of the TP loading was exported during storm and intermediate flow periods, whereas most of the SRP loading was delivered during low and intermediate flow periods. Our results underscored the important role of stream hydrology in controlling the loading and transport of $\mathrm{P}$ across the watershed as it dictated the amount, form, and timing of P delivery to Lake Erie. We suggest that an improved understanding of the major biogeochemical processes involved is required in order to develop a better P management practice for restoration of the Cuyahoga River and Lake Erie as well.

\section{Acknowledgments}

We gratefully acknowledge E. Butler and R. Yuan for their assistance in field sampling and J. Cramer for chemical analyses of water samples, and J.W. Rhoades and G. Stadler for providing their effluent monitoring data. This paper has benefited from thoughtful discussions with R.P. Richards, D. Baker, S. Hothem, and B. Zawiski. We thank three anonymous reviewers for their valuable comments and suggestions that helped us greatly improve the presentation of this manuscript. This work was partially supported by a small grant from the Ohio Lake Erie Commission (Grant No. LEPF325-07).

\section{References}

Baker, D.B., 2005. Loading Calculations, Annual Loads and Unit Area Load. Water Quality Laboratory, Heidelberg College. <http://www.heidelberg.edu/ academiclife/distinctive/ncwqr/data/guide> (accessed 20.12.11).

Baker, D.B., 2007. Phosphorus Loading to Lake Erie: A Brief Overview, Including Recent Changes in Dissolved Reactive Phosphorus from Tributaries. Ohio Environmental Protection Agency, p. 5. <http://www.epa.ohio.gov/portals/35/ lakeerie/ptaskforce/BakerBullets.pdf> (accessed 04.01.12).

Baker, D.B., Kramer, J.W., 1973. Phosphorus sources and transport in an agricultural river basin of Lake Erie. In: International Association for Great Lakes Research, 16th Annual Conference of Great Lakes Research, pp. 858-871.

Balanson, S., Walton, B.M., Wolin, J.A., Mal, T.K., 2005. Aquatic macrophyte diversity and habitat characterization of the Cuyahoga River watershed in northeastern Ohio. Ohio J. Sci. 105, 88-96.

Beeton, A.M., 1961. Environmental changes in Lake Erie. Trans. Am. Fish. Soc. 90, 153-159.
Bowes, M.J., Smith, J.T., Neal, C., Leach, D.V., Scarlett, P.M., Wickham, H.D., Harman, S.A., Armstrong, L.K., Davy-Bowker, J., Haft, M., Davies, C.E., 2011. Changes in water quality of the River Frome (UK) from 1965 to 2009: is phosphorus mitigation finally working? Sci. Total Environ. 409, 3418-3430.

Brown, B.J., Olive, J.H., 1995. Diatom communities in the Cuyahoga River (USA) changes in species composition between 1974 and 1992 following renovations in waste-water management. Ohio J. Sci. 95, 254-260.

Carey, R.O., Migliaccio, K.W., 2009. Contribution of wastewater treatment plant effluents to nutrient dynamics in aquatic systems: a review. Environ. Manage. 44, 205-217.

Carpenter, S.R., Caraco, N.F., Correll, D.L., Howarth, R.W., Sharpley, A.N., Smith, V.H., 1998. Nonpoint pollution of surface waters with phosphorus and nitrogen. Ecol. Appl. 8, 559-568.

Conroy, J.D., Kane, D.D., Dolan, D.M., Edwards, W.J., Charlton, M.N., Culver, D.A. 2005. Temporal trends in Lake Erie plankton biomass: Roles of external phosphorus loading and dreissenid mussels. J. Great Lakes Res. 31 (Suppl. 2) 89-110.

Correll, D.L., 1998. The role of phosphorus in the eutrophication of receiving waters: a review. J. Environ. Oual. 27, 261-266.

Crumrine, J., 2009. Soil Phosphorus Stratification with Reduced Tillage. National Center for Water Quality Research, Heidelberg University, Tiffin, OH, p. 22 $<$ http://www.lakeerie.ohio.gov/ LinkClick.aspx?fileticket=Il1hE\%2FEazYU\%3D\&tabid=61> (accessed 08.01.12).

Daloğlu, I., Cho, K.H., Scavia, D., 2012. Evaluating causes of trends in long-term dissolved reactive phosphorus loads to Lake Erie. Environ. Sci. Technol. 46 10660-10666.

Dolan, D.M., Chapra, S.C., 2012. Great Lakes total phosphorus revisited: 1. Loading analysis and update (1994-2008). J. Great Lakes Res. 38, 730-740.

Dolan, D.M., McGunagle, K.P., 2005. Lake Erie total phosphorus loading analysis and update: 1996-2002. J. Great Lakes Res. 31, 11-22.

Gustafsson, B.G., Schenk, F., Blenckner, T., Eilola, K., Meier, H.E.M., Müller-Karulis, B. Neumann, T., Ruoho-Airola, T., Savchuk, O., Zorita, E., 2012. Reconstructing the development of Baltic Sea Eutrophication 1850-2006. Ambio 41, 534-548.

Hartig, J.H., Trautrim, C., Dolan, D.M., Rathke, D.E., 1990. The rationale for Ohio's detergent phosphorus ban. J. Am. Water Resour. Assoc. 26, 201-207.

Hawley, N., Johengen, T.H., Rao, Y.R., Ruberg, S.A., Beletsky, D., Ludsin, S.A., Eadie, B.J., Schwab, D.J., Croley, T.E., Brandt, S.B., 2006. Lake Erie hypoxia prompts Canada-U.S. study. Eos Trans. AGU 87, 313-324.

House, W.A., 2003. Geochemical cycling of phosphorus in rivers. Appl. Geochem. 18, $739-748$.

Howden, N.J.K., Burt, T.P., 2008. Temporal and spatial analysis of nitrate concentrations from the Frome and Piddle catchments in Dorset (UK) for water years 1978 to 2007: evidence for nitrate breakthrough? Sci. Total Environ. 407, 507-526.

Jarvie, H.P., Neal, C., Williams, R.J., Neal, M., Wickham, H.D., Hill, L.K., Wade, A.J., Warwick, A., White, J., 2002. Phosphorus sources, speciation and dynamics in the lowland eutrophic River Kennet, UK. Sci. Total Environ. 282, 175-203.

Jarvie, H.P., Neal, C., Withers, P.J.A., 2006. Sewage-effluent phosphorus: a greater risk to river eutrophication than agricultural phosphorus? Sci. Total Environ. 360, 246-253.

Lo, H.H., Shong, A.A., 1976. Geochemical investigation of the lower Cuyahoga River, Cleveland, Ohio. Ohio J. Sci. 76, 57-76.

Marti, E., Aumatell, J., Gode, L., Poch, M., Sabater, F., 2004. Nutrient retention efficiency in streams receiving inputs from wastewater treatment plants. J. Environ. Qual. 33, 285-293.

Michalak, A.M., Anderson, E.J., Beletsky, D., Boland, S., Bosch, N.S., Bridgeman, T.B., Chaffin, J.D., Cho, K., Confesor, R., Daloğlu, I., DePinto, J.V., Evans, M.A. Fahnenstiel, G.L., He, L., Ho, J.C., Jenkins, L., Johengen, T.H., Kuo, K.C., LaPorte, E., Liu, X., McWilliams, M.R., Moore, M.R., Posselt, D.J., Richards, R.P., Scavia, D. Steiner, A.L., Verhamme, E., Wright, D.M., Zagorski, M.A., 2013. Record-setting algal bloom in Lake Erie caused by agricultural and meteorological trends consistent with expected future conditions. Proc. Nat. Acad. Sci. 110, 64486452.

Myers, D.N., Koltun, G.F., Francy, D.S., 1998. Effects of Hydrologic, Biological, and Environmental Processes on Sources and Concentrations of Fecal Bacteria in the Cuyahoga River, with Implications for Management of Recreational Waters in Summit and Cuyahoga Counties, Ohio. U.S. Geological Survey Water-Resources Investigations, Report 98-4089.

Myers, D.N., Metzker, K.D., Davis, S., 2000. Status and Trends in SuspendedSediment Discharges, Soil Erosion, and Conservation Tillage in the Maumee River Basin-Ohio, Michigan, and Indiana. U.S. Geological Survey and U.S. Department of Agriculture, Natural Resources Conservation Service, WaterResources Investigations Report 00-4091, p. 45.

NCWQR, 2010. The Heidelberg tributary loading program. National Center for Water Quality Research (NCWQR), Heidelberg University, Tiffin, Ohio. <http:// www.heidelberg.edu/wql> (accessed 05.12.10).

NWIS, 2011. USGS 04208000 Cuyahoga River at Independence OH. <http:// waterdata.usgs.gov/oh/nwis/nwisman/?site no=04208000> (accessed 27.12.11).

OEPA, 1999. Biological and Water Quality Study of the Cuyahoga River and Selected Tributaries. Ohio Environmental Protection Agency (OEPA), Division of Surface Water, p. 141.

OEPA, 2003. Total Maximum Daily Loads for the Lower Cuyahoga River. Ohio Environmental Protection Agency (OEPA), Division of Surface Water, p. 102.

OEPA, 2010. Ohio Lake Erie Phosphorus Task Force Final Report. Division of Surface Water, Ohio Environmental Protection Agency, Columbus, Ohio, p. 109. 
Richards, R.P., Baker, D.B., Kramer, J.W., Ewing, D.E., Merryfield, B.J., Miller, N.L. 2001. Storm discharge, loads, and average concentrations in northwest Ohio rivers, 1975-1995. J. Am. Water Resour. Assoc. 37, 423-438.

Richards, R.P., Baker, D.B., Crumirine, J.P., Kramer, J.W., Ewing, D.E., Merryfield, B.J. 2008. Thirty-year trends in suspended sediment in seven Lake Erie tributaries. J. Environ. Qual. 37, 1894-1908.

Richards, R.P., Baker, D.B., Crumrine, J.P., 2009. Improved water quality in Ohio tributaries to Lake Erie: a consequence of conservation practices. J. Soil Water Conserv. 64, 200-211.

Rumschlag, J.H., Peck, J.A., 2007. Short-term sediment and morphologic response of the middle Cuyahoga River to the removal of the Munroe Falls Dam, summit county, Ohio. J. Great Lakes Res. 33, 142-153.

Schindler, D.W., 1974. Eutrophication and recovery in experimental lakes: implications for lake management. Science 184, 897-899.

Schindler, D.W., Hecky, R.E., Findlay, D.L., Stainton, M.P., Parker, B.R., Paterson, M.] ., Beaty, K.G., Lyng, M., Kasian, S.E.M., 2008. Eutrophication of lakes cannot be controlled by reducing nitrogen input: results of a 37-year whole-ecosystem experiment. Proc. Natl. Acad. Sci. 105, 11254-11258.
Schroeder, M.E., Collier, C.R., 1966. Water-Quality Variations in the Cuyahoga River at Cleveland, Ohio. U.S. Geological Survey Professional Paper 550-C, pp. C251C255.

Schwab, D.J., Beletsky, D., DePinto, J., Dolan, D.M., 2009. A hydrodynamic approach to modeling phosphorus distribution in Lake Erie. I. Great Lakes Res, 35, 50-60.

Stumpf, R.P., Wynne, T.T., Baker, D.B., Fahnenstiel, G.L., 2012. Interannual variability of cyanobacterial blooms in Lake Erie. PLoS One 7, 54.

Tuckerman, S., Zawiski, B., 2007. Case studies of dam removal and TMDLs: process and results. J. Great Lakes Res. 33, 103-116.

Withers, P.J.A., Jarvie, H.P., 2008. Delivery and cycling of phosphorus in rivers: a review. Sci. Total Environ. 400, 379-395.

Yuan, F. Miyamoto, S. 2004. Influence of the Pacific Decadal Oscillation on hydrochemistry of the Rio Grande, USA, and Mexico. Geochem. Geophys. Geosyst. 5, 1-10.

Yuan, F., Miyamoto, S., Anand, S., 2007. Changes in major element hydrochemistry of the Pecos River in the American Southwest since 1935. Appl. Geochem. 22, 1798-1813. 